International Journal of Child, Youth and Family Studies (2013) 3.1: 464-474

\title{
A MOVEMENT TO BELONG: THE GREEN MOVEMENT AS A SITE OF CITIZENSHIP
}

\section{Maryam Nabavi and Romina Mahboub}

\begin{abstract}
Drawing on ethnographic data collected in 2010, this paper unpacks the notion of social citizenship as it bears on the lives of young Iranian immigrant activists in Canada. Drawing on our researcher and activist standpoints, we examine activist youth's involvement in the Green Movement - a global movement of dissent in response to the 2009 presidential elections in Iran. In doing so, we move beyond the duality of identity and belonging as mediated by a sense of nationhood to either Iran or Canada. Rather, through the lens of social citizenship, we shed light on the ways in which the Green Movement, as an activist practice, was a space of emancipation. We explore the ways in which support for and momentum of an initiative created and led by youth enabled them to engage as citizens in ways that challenged the notion that citizenship is defined merely by geographic borders; globalized social, cultural, and political contexts were more significant in characterizing their citizenship.
\end{abstract}

Keywords: social citizenship, citizen, Green Movement, youth, learning, diaspora, duoethnography, activist, immigrant

Maryam Nabavi, Ph.D. (the corresponding author) received her doctorate in Educational Studies from the University of British Columbia in 2011. Maryam Nabavi, 101, 1950 East $11^{\text {th }}$ Avenue, Vancouver, British Columbia, Canada, V5N 1Z2. E-mail: Maryam.nabavi@gmail.com

Romina Mahboub is a student in the Faculty of Applied Sciences at Simon Fraser University, 8888 University Drive, Burnaby (British Columbia), Canada, V5A 1S6. E-mail:

romina_mahboub@hotmail.com 
International Journal of Child, Youth and Family Studies (2013) 3.1: 464-474

Natarsid! Natarsid! Ma hame ba ham hastim. Don't be afraid! Don't be afraid! We are all together.

The above chant echoed throughout Iran as thousands of civilians poured into the streets of major cities throughout the nation to protest the outcome of the June 12, 2009 presidential elections. The collective call to not fear was, specifically, a call to stand up to a regime in which freedom of expression, democracy, and equal opportunities, as well as social, political, cultural, religious, and economic rights were a threat. The demonstrations were unique, not only because they were the largest in Iran's post-revolutionary history, but also because young people led the demands for change just as in the case of Egypt, less than two years later. They were unique also because of the global nature of the call for change.

The Iranian diaspora played a significant role in creating awareness of the civil rights movement in places as far from Tehran as Tokyo and as close as Istanbul. The movement for change, started by young Iranians in Iran with young Iranians across the globe joining in, was leaderless and fuelled by its commitment to democracy and human rights (Hashemi \& Postel, 2010). It was coined the Green Movement because green was the campaign colour of the forerunning challenger, Mir-Hossein Mousavi. However, green eventually came to symbolize international unity to those asking for change in Iran.

In Vancouver, Canada, numerous formal and loosely organized grassroots efforts committed to the Green Movement arose in the days immediately following the elections in Iran. These efforts were orchestrated by young diasporic Iranians, some of whom had been living outside of Iran longer than they had lived inside the country.

In this article, we explore the Green Movement as a site of citizenship for young Iranians from the perspectives of a researcher (Nabavi) and an activist (Mahboub) involved in the movement. We are inspired by the duoethnographic approach (Norris, Sawyer, \& Lund, 2012), a methodology in which the lived experiences of the authors are central to unpacking the topics of exploration. We draw on our researcher and activist positions within the Green Movement in order to analyze the notion of what it means to be a citizen and show how citizenship is a process of learning mediated by action.

Our starting point is an exploration of the ways in which our status as Iranian-Canadians informs our sense of identity and belonging in the diaspora. However, we move beyond the duality of identity and belonging as mediated by a sense of nationhood to either Iran or Canada. Rather, through the lens of social citizenship, we shed light on the ways in which the Green Movement, as an activist practice, was a space that fostered a sense of identity, belonging, and emancipation. We explore the ways in which support for and momentum of an initiative created and led by youth enabled them to engage as citizens in ways that challenged the notion that citizenship is defined merely by geographic borders; globalized social, cultural, and political contexts were more significant in characterizing their citizenship.

Maryam: As a recent doctoral graduate in Educational Studies, I am excited to not only share insights from one piece of my dissertation research (Nabavi, 2011), which explored young 
International Journal of Child, Youth and Family Studies (2013) 3.1: 464-474

Iranian immigrant activist efforts in Vancouver, but to be doing so with someone who is an Iranian immigrant activist. It is a pleasure to be writing this article with Romina, whom I met in 2010 during research.

I am an academic and former youth activist committed to issues concerning social, cultural, political, and spatial inclusions and exclusions. These commitments are fuelled by my own experiences of immigration and belonging within a multicultural nation state (Nabavi \& Lund, 2012). Aside from my personal interests in the Green Movement - a movement that I was unequivocally a member of, by virtue of being from Iran and emigrating because of the very regime which the Green Movement was reacting to - as a researcher, I found myself asking the following questions: Why were young Iranian immigrants engaged in a movement that they were not directly impacted by and in a country that they had emigrated from at a young age? What were the experiences of immigrant youth who were involved in the Green Movement? And, more specifically, how could those experiences help us in understanding what it means to be a citizen in Canada? Romina, tell me about your experiences as an immigrant youth in Canada and your motivations for being involved in the Green Movement.

Romina: Maryam, exploring the concept of citizenship through my involvement in the Green Movement has been an opportunity to reflect on my experiences of being an immigrant youth in Canada. I was 12 years old when I arrived in Canada. Although I am now 24 years old, I still consider myself a youth. I feel strongly about the possibilities for social change and believe that youth not only have the thirst and determination to create change, but that they are often at the forefront of it. So, although I may not fall within the conventional age parameters assigned to youth, I situate myself as a youth in my commitments and actions.

My belief that change is possible ignited my involvement in the Green Movement. Being an immigrant youth, especially one whose native country is in a state of unrest, fuelled my commitment to engaging in any way I could with the very issues that led to my and my family's emigration, and to contributing to the process of democracy for my fellow Iranians living in Iran.

During childhood years in Iran, I quickly learned to be two people at the same time. As my family's core values are in opposition to the values of the current Iranian regime, creating a second persona for the outside world was a way of survival. For example, who I was in school was not a clear reflection of my true being. The differences between how I was supposed to behave at home and at school were minor when I was in elementary school. However, as I grew older, I learned to switch to the outside persona who adhered to the fundamental Islamic values that permeated society as soon as I stepped out of my home. This duality was one of the many reasons driving my family to emigrate.

Shortly after our move to Canada, my family and I realized that the "normal" environment that we were striving for had its own limitations, and it was in Canada that I experienced duality again. While immigration can be rewarding in many respects, it has its disadvantages, such as the cultural confusion experienced by the émigré. As a youth, immigration was the biggest shift of my life. I was living the life of an Iranian youth in Canadian society; I was reliving the life I had in Iran, but in a different world, with different limitations 
International Journal of Child, Youth and Family Studies (2013) 3.1: 464-474

and opportunities. In Canada, as a teenager, my home seemed like the limitation and the outside world was the opportunity.

So it is not by accident that ever since I was young, I have been interested in understanding the reasons behind this duality. Politics seemed to be behind all the confusion developed during my life in Iran and it was through my involvement in the political scene in Canada that I realized I have the right as a citizen - a Canadian citizen - to step towards change. It was my hope that this change would ultimately make Iran more livable. In other words, it would be a place where differences were celebrated rather than condemned, and children wouldn't have to develop a second persona for survival.

My involvement in the Green Movement was an effort to make these changes happen in Iran. After the 2009 elections, I quickly realized that I was a citizen of Iran only in the official sense of carrying a passport. I recognized how desperately I was looking to be an Iranian beyond either an official status or a cultural identity in Canada. I felt invested in the politics of "home" as I wanted to also be Iranian. My activism in the Green Movement provided a space to do that.

Maryam: Romina, as you share your experiences, I am reminded of the ways that you, like many other immigrant youth today, are embedded in what Stuart Hall (1996) poignantly calls new ethnicities. These are defined by the ways in which locality, culture, migration, and language within an increasingly globalized landscape inform the ways in which dominant markers of identity are articulated. Engagement with their new ethnicities entails that immigrant youth are not "passive recipients of social transformations, as may have been assumed, but are responding to change in a variety of ways that draw upon the signs, symbols and motifs made available at local, national and international scales” (Nayak, 2003, p. 167). All youth, as Giroux (2006) argues, are made to be political subjects and take on political identities as a way to belong. Thus, it can be argued that for immigrant youth, new ethnicities, coupled with the current realities facing youth in general, contribute to the ways in which they engage with and learn to be citizens.

Based on our earlier conversations about our own experiences of emigration and immigration and how we situate ourselves as Iranian and Canadian, I would argue that we live in an era in which the lines between national and global identities and belongings are increasingly blurred, and that there is an urgent need to situate citizenship in ways other than those that emphasize status, rights, and duties. An exploration of citizenship must take into consideration the foundational dimensions - the interplay of civil, political, and social rights (Marshall, 1965) - as they intersect with historical and contemporary contexts of individual, cultural, and institutional identities and belongings. This approach to citizenship which falls under the canopy of social citizenship (Miller, 2002; Rosaldo, 1999) responds to the limitations of contemporary conceptions of citizenship in Canada, which are associated with particular moral, political, and cultural claims closely aligned with a multicultural national identity (Mitchell, 2003). To this end, I think the notion of "belonging" is central to how we understand social citizenship. What are your experiences of belonging in Canada as a young immigrant?

Romina: Shortly after coming to Canada I realized that starting a new life in a new country and learning a new culture would not necessarily erase my past and my origin. On the 
contrary, it would build upon it. This realization was informed by my positive experiences of feeling welcomed in Canada. For example, my high school held an annual multicultural week; students from different backgrounds came together to teach others about their food, music, dance, and culture. This sort of celebration was useful as it allowed me to endorse my Iranian culture and heritage amongst my peers and, in many ways, it helped me maintain pride and acceptance of my culture, which I was afraid of losing after immigration. These sorts of experiences were so rewarding that I was able to shape my Canadian identity through my Iranian heritage.

My early positive experiences with multiculturalism were valuable for teaching me both how to be a leader and how to implement my thirst for change in my new context. Through external affirmation of pride for my culture and celebration of the duality, I learned that my identity as a youth, a student, and an immigrant in Canada were points of entry for being a leader; this was starkly different than my experiences in Iran. For example, I was given the opportunity to be involved in the Youth Advisory Committee for the district of West Vancouver. Although my language skills were limited, it did not stop any of the committee members from listening to my opinions. This helped me build a sense of agency and belief that I could be an active citizen in Canada.

I believe adaptation can happen regardless of the situation, but its process can be turbulent or smooth according to one's new environment. As I belonged to two different places at the same time and because my Canadian experiences yielded opportunities to highlight my Iranian identity, I felt like I was able to have the best of both worlds and willingly adopt the identity of an Iranian-Canadian.

Maryam: Although we immigrated 15 years apart, in both our experiences of being a youth arriving in Canada, we experienced a loss of belonging to one place (Iran), which didn't necessarily coincide with an automatic sense of belonging to another (Canada). The contexts of migration - both forced and free - are always marked by a reminder of the "home" that is left behind. The need to "belong" is a central characteristic of youth culture (Giroux, 2006; Maira, 2004; Nayak, 2003; Pilkington \& Johnson, 2003), which is amplified for immigrant youth who are tasked with the additional burden of negotiating the differences of familial and peer, and ethnic and mainstream contexts in their lives. As with other young immigrants, the need to belong not just to our adopted culture, but also to the culture left behind, is what makes one feel like a citizen.

It seems like your experiences of belonging were largely informed by the ways that the celebratory dimensions of multiculturalism played out in your life. Similarly, the participants in my study expressed a range of meanings and interpretations of the official and unofficial discourses of multiculturalism and how they felt they were positioned as citizens. Some of the young people I spoke with held similar views to yours - that on the whole their experiences in multicultural Canada enabled them to celebrate their heritage and, in effect, feel that they were integral to the Canadian milieu, and to see themselves as citizens. However, the majority of the people I spoke with drew attention to the ways in which their Canadian experiences were coloured with discrimination and exclusion, and they experienced their Canadian citizenship as nothing more than a passport. The range of perspectives reaffirmed the critical views of 
International Journal of Child, Youth and Family Studies (2013) 3.1: 464-474

Canadian leftist multiculturalists that discourses and lived experiences of multiculturalism exist between inclusion and exclusion (Giroux, 2006; Steinberg, 2001).

In spite of the differing perspectives, individuals' informal lived experiences influenced the meanings and interpretations they gave to citizenship. I think one of the ways that young Iranian immigrants make sense of their experiences is to find belonging in the hyphen of their Iranian-Canadian identity and, in effect, to create a new hybrid identity (Nabavi, 2012). For immigrants, the relationship between belonging and feeling like a citizen are closely connected. However, unlike conventional conceptions of being a citizen and citizenship that draws attention to a shared identity informed by common national boundaries, belonging, for immigrants, is within and across transnational social and political spaces which shape notions of identity and belonging (Castles, 2004). As you mention, your involvement in the Green Movement was shaped by the contexts and experiences surrounding your immigration experience, so in effect, the boundaries of the nation become less important for how you belong. Similarly, while I identify as an Iranian-Canadian, this identity is far more a social, cultural, and political identity than it is a geographic one.

The Green Movement was central to how the participants expressed their sense of identity and belonging in Canada (or their social citizenship). I'm interested to know if your experiences in Canada were in any way a source of motivation for being involved.

Romina: As youth - and particularly as immigrant youth - we are often positioned without social capital and socio-political influence. Yet, our desires to belong and make sense of our dual identities and be part of a larger movement were factors that led to, what many would argue, was the success of the Green Movement.

For me, the idea of belonging came about through an opportunity in my new country to stand up for the rights of Iranian people in Iran. After the presidential election, when many Iranian people believed that the government ignored their votes, a silent revolution started. A new wave of hope was generated and a sense of identity within the Iranian community, especially among the youth, was created (Dabashi, 2011). When the results of the election were announced, hundreds of Vancouverites, mostly Iranian-Canadians, gathered for ten consecutive nightly vigils in front of the Vancouver Art Gallery for what was called the Silent Scream - a show of support for those in Iran who too felt that the election was undemocratic. The vigils were envisioned and organized by youth and they attracted diverse and unprecedented intergenerational participation from across the Iranian immigrant community. For me, this was telling of how an issue can affect youth and adults in the same way and, more importantly, of how youth are able to mobilize and organize with the support and participation of non-youth. This success made us feel we were not just part of a movement, but that we were the movement.

In addition to the youth-led leadership that the Green Movement facilitated, it was also instrumental in forming the identities of many youth who participated. Like many friends who were actively involved, I engaged with and understood more fully my identity as an IranianCanadian in ways I had not in the past. I was able to engage in the very political issues that drove my family to emigrate while doing so freely as a Canadian. For me, this transcended being 
International Journal of Child, Youth and Family Studies (2013) 3.1: 464-474

Iranian or Canadian or just a hyphen between the two - it was an identity that was rooted in the global contexts that I am embedded in.

We both organized and mobilized, which made me believe that youth are able to ignite change and fuel it concurrently. It was through this movement that I realized that youth do not need to depend on adults and that we can reach what is desired. I think it would be ideal to have youth participation and leadership coupled with the timeless experiences of adults, along with adults' encouragement, and the ability to consult with them. For me, this is the essence of youth emancipation.

Maryam: Thank you for sharing your experiences. You provide a concrete example of how being part of a movement, particularly across national belongings, allows us to be citizens. I think that while the motivation for many to be involved in the Green Movement was informed by a commitment to justice, shared values, and sovereignty, it was also a response to nostalgia for a place to which it may be impossible or undesirable to return. No longer fully belonging to the country from which one has emigrated or to the country of immigration, Iranian migrants in many respects inhabit a space in between two or more places, as you eloquently articulated above.

Let me share my own experiences. Like you, I often experience a duality insofar as I am invested in the social, cultural, and political contexts of both Iran and Canada. However, as someone who has had my formative experiences in Canada, the ways in which I am invested in Iran are not as an Iranian, per se, but rather as an Iranian living in the diaspora. At the same time, as a Canadian, I am partial to the well-being of Iranians living within and outside of Iran. Thus, the ways in which I inhabit a space as both an Iranian and Canadian are complex, though perhaps not uncommon. This ultimately shapes my sense of identity and what it means to belong. Furthermore, it informs the way I view myself as a citizen of a place and my notions of citizenship.

One of the findings in my study with young immigrants (many of whom self-identified as activists) is that the notion of being a citizen is linked with action. In other words, one does not become a citizen through state-imposed criteria such as having a passport. Rather, becoming a citizen and having a sense of citizenship is a process that is constantly changing based on an individual's stage in development and the circumstances through which it was acquired. Elsewhere, I have argued that this approach to understanding citizenship takes into account issues of identity, representation, membership, and engagement (Nabavi, 2010).

For example, there may be significant differences in how two citizens of Canada engage with their formal citizenship based on their process of acquiring citizenship. The processes of understanding and even engaging with citizenship are different for an individual whose citizenship is granted as a birthright and for a refugee who acquires formal citizenship only after being granted asylum and undergoing a lengthy bureaucratic process. Thus, for migrants, social dimensions of citizenship, such as a sense of belonging, both inform and are informed by formal dimensions of citizenship. While different connections to homeland and the meanings and interpretations this has for citizenship have been widely studied (Ong, 1999; Soysal, 2000; Yuval-Davis, 1997) and are valuable for understanding the ways in which young immigrants 
International Journal of Child, Youth and Family Studies (2013) 3.1: 464-474

were involved in the Green Movement, it is also valuable to explore how young Iranian immigrants' experiences (as citizens and with citizenship) in Canada mediated their involvement in the Green Movement. What are your thoughts on this?

Romina: The Green Movement of Vancouver consisted mostly of students. Within this student body, there was diversity. There were second generation Iranians who had never been to Iran, but had a passion for making change in our home country; there were some who had lived most of their lives in Iran but had to leave their home due to the political situation there; and there were some, just like me, who identified as both Iranian and Canadian, who felt compelled to practice their rights as Canadians to be loud and inquisitive, and to ask for justice in their home country. Our experiences in Canada varied and we had all experienced inclusion and exclusion in many forms.

Despite our varied backgrounds, the idea of a democratic Iran was our common denominator. I wonder if this was the case because we felt nationalistic towards Iran or because we were nostalgic for an imagined and romanticized place of our past. In other words, do we consider ourselves Iranians or Iranian-Canadians? And do we want to identify as Iranians beyond a cultural identity only when democracy is achieved?

Do you think the reason Iranians, especially youth, came together so quickly during the aftermath of the presidential elections was solely because they wanted an opportunity to see their home country change to their ideal state - an imagined Iran of their past? Or do you think it was driven by a desire to feel a sense of belonging as active citizens (Sears \& Hughes, 1996) in Canada, by using a situation with which they felt an affinity as a launching pad?

Maryam: This is a really good question and I don't think there was only one reason that motivated the activism. I find the framework of diaspora studies useful for unpacking the motivations of the young immigrants involved in the Green Movement and, in effect, understanding how the impact of their involvement was emancipatory. In Safran's (1991) classic heuristic of diaspora, four out of six characteristics are concerned with homeland. These include:

first, maintaining a collective memory or myth about the homeland; second, "regarding the ancestral homeland as the true, ideal home and as the place to which one would (or should) eventually return"; third, being collectively "committed to the maintenance or restoration of the homeland and to its safety and prosperity"; and fourth, "continu[ing] to relate, personally or vicariously", to the homeland, in a way that significantly shapes one’s identity and solidarity. (Safran, 1991, as cited in Brubaker, 2005, p. 5)

These criteria of orientation to homeland are not just simple yearning for an imagined or real nation. As Werbner (2002) argues, "many diasporas are deeply implicated both ideologically and materially in the nationalist projects of their homelands" (p. 120); thus a central feature of organizing as a diaspora community is to mobilize around national and ethnic symbols that serve as a resource to strengthen a diaspora identity (Anthias, 2009).

So, in effect, for the activists involved in the Green Movement, knowing that their efforts could lead to a change in Iran to the point that they would find it desirable to return was, I think, 
a real motivation. Equally central was that their efforts, just as in your experience, were motivated by a sense of belonging to Canada by building a strong diaspora identity. I do not believe the nationalist project of Iran was the sole motivation. Rather, resisting, mobilizing, and educating as engaged citizens were central characteristics to the movement; it was not a practice of citizenship that was informed by a place, but rather informed by the broader conceptions of being a citizen within the global context.

Like you, the decision to be involved in the Green Movement for all the people I spoke with was grounded within their globalized experiences of citizenship, such as how they were implicated within the structures of inclusion and exclusion in both Iran and Canada. What this highlights is that involvement in the Green Movement for young Iranian immigrants in Canada was a response to substantive and social dimensions of citizenship in both Iran and Canada and, simultaneously, a process of learning citizenship and becoming a citizen.

In terms of our understanding of youth emancipatory practices, we can gather that for immigrant youth, being involved in a movement that straddles their national and cultural identities and troubles dominant conceptions of citizenship, is an emancipatory practice insofar as providing space to be a citizen, to belong, and to explore a sense of identity.

Romina: This makes sense to me as after the elections, I felt compelled to do something about my people, my homeland, and most importantly, about my feelings of nostalgia for Iran. Being involved in the Green Movement was not solely to fulfill my obligations as an Iranian citizen, but rather to consciously involve myself in a movement in which the possibility of a better future for my homeland could be created. It was through my activism that I gained the power to speak up to my community (both Iranian and the community at large) and also to politicians and the media in order to give voice to the voiceless in my home country. It was through that power that I realized I have the potential of creating change, or at least the possibility of change, for something so dear to my heart. As a youth, a student, or simply an immigrant, I had the power of change and that to me is what citizenship means. It was through this I experienced a sense of belonging, and a citizenship that is not limited to a document, and I was able to internalize where I situate myself as an Iranian-Canadian. 
International Journal of Child, Youth and Family Studies (2013) 3.1: 464-474

\section{References}

Anthias, F. (2009). Thinking through the lens of translocational positionality: An intersectionality frame for understanding identity and belonging. Translocations: Migration and social change, 4(1), 5-20.

Brubaker, R. (2005). The "diaspora" diaspora. Ethnic and Racial Studies, 28(1), 1-19. doi: $10.1080 / 0141987042000289997$

Castles, S. (2004). Migration, citizenship, and education In J. A. Banks (Ed.), Diversity and citizenship education: Global perspectives (pp. 17-48). San Francisco: Jossey-Bass.

Dabashi, H. (2011). The Green Movement in Iran. New Brunswick, NJ: Transaction Publishers.

Giroux, H. (2006). The Giroux reader. London: Paradigm Publishers.

Hall, S. (1996). New ethnicities. In D. Morley \& K.-H. Chen (Eds.), Stuart Hall: Critical dialogues in cultural studies (pp. 441-449). New York: Routledge.

Hashemi, N., \& Postel, D. (Eds.). (2010). The people reloaded: The Green Movement and the struggle for Iran's future. New York: Melville House.

Maira, S. (2004). Youth culture, citizenship and globalization: South Asian Muslim youth in the United States after September 11th. Comparative Studies of South Asia, Africa and Middle East, 24(1), 219-231.

Marshall, T. H. (1965). Citizenship and social class. In T. H. Marshall \& T. Bottomore (Eds.), Citizenship and social class (pp. 3-51). London: Pluto Press.

Miller, T. (2002). Cultural citizenship. In E. F. Isin \& B. S. Turner (Eds.), Handbook of citizenship studies (pp. 231-244). London: Sage Publications.

Mitchell, K. (2003). Educating the national citizen in neoliberal times: From the multicultural self to the strategic cosmopolitan. Transactions of the Institute of British Geographers, 28(4), 387-403. doi: 10.1111/j.0020-2754.2003.00100.x

Nabavi, M. (2010). Constructing the "citizen" in citizenship education. Canadian Journal for New Scholars in Education, 3(1), 1-10.

Nabavi, M. (2011). (Un)learning citizenship in Canada: Iranian immigrant youth's silences, contradictions, and expressions. Unpublished doctoral dissertation, The University of British Columbia, Vancouver.

Nabavi, M. (2012). Identity roots and political routes: Immigrant youth and the political poetics of multiculturalism. In H. Wright, M. Singh, \& R. Race (Eds.), Precarious international 
International Journal of Child, Youth and Family Studies (2013) 3.1: 464-474

multicultural education: Hegemony, dissent and rising alternatives (pp. 153-168). Rotterdam, The Netherlands: Sense Publishers.

Nabavi, M., \& Lund, D. (2012). The tensions and contradictions of living in a multicultural nation in an era of bounded identities. In J. Norris, R. Sawyer, \& D. Lund (Eds.), Duoethnography: Promoting personal and societal change in dialogic self-study (pp. 177-197). Rotterdam, The Netherlands: Sense Publishers.

Nayak, A. (2003). Race, place and globalization: Youth cultures in a changing world. Oxford: Berg.

Norris, J., Sawyer, R., \& Lund, D. (Eds.). (2012). Duoethnography: Promoting personal and societal change in dialogic self-study. Rotterdam, The Netherlands: Sense Publishers.

Ong, A. (1999). Flexible citizenship: The cultural logic of transnationality. London: Duke University Press.

Pilkington, H., \& Johnson, R. (2003). Peripheral youth: Relations of identity and power in global/local relations. European Journal of Cultural Studies, 6(3), 259-283. doi: $10.1177 / 13675494030063001$

Rosaldo, R. (1999). Cultural citizenship, inequality, and multiculturalism. In R. D. Torres, L. F. Mirón, \& J. X. Inda (Eds.), Race, identity, and citizenship: A reader (pp. 253-263). Malden, MA: Blackwell Publishers.

Safran, W. (1991). Diasporas in modern societies: Myths of homeland return. Diaspora, 1(1), 83-89. doi: 0.1353/dsp.1991.0004

Sears, A., \& Hughes, A. (1996). Citizenship education and current educational reform. Canadian Journal of Education, 21(2), 123-142.

Soysal, Y. (2000). Citizenship and identity: Living in diasporas in post-war Europe? Ethnic and Racial Studies, 23(1), 1-15. doi: 10.1080/014198700329105

Steinberg, S. (2001). Multi/intercultural conversations: A reader. New York: Peter Lang Publishers.

Werbner, P. (2002). The place which is diaspora: Citizenship, religion and gender in the making of chaordic transnationalism. Journal of Ethnic and Migration Studies, 28(1), 119-133. doi: 10.1080/13691830120103967

Yuval-Davis, N. (1997). Ethnicity, gender relations and multiculturalism. In P. Werbner \& T. Modood (Eds.), Debating cultural hybridity (pp. 193-208). London: Zed Books. 